\title{
Effects of permafrost collapse on soil bacterial communities in a wet meadow on the northern Qinghai-Tibetan Plateau
}

\author{
Xiaodong $\mathrm{Wu}^{1 *}$, Haiyan $\mathrm{Xu}^{2}$, Guimin $\mathrm{Liu}^{2}$, Lin Zhao ${ }^{1}$ and Cuicui $\mathrm{Mu}^{3}$
}

\begin{abstract}
Background: Permafrost degradation may develop thermokarst landforms, which substantially change physicochemical characteristics in the soil as well as the soil carbon stock. However, little is known about changes of bacterial community among the microfeatures within thermokarst area.

Results: We investigated bacterial communities using the Illumina sequencing method and examined their relationships with soil parameters in a thermokarst feature on the northern Qinghai-Tibetan Plateau. We categorized the ground surface into three different micro-relief patches based on the type and extent of permafrost collapse (control, collapsing and subsided areas). Permafrost collapse significantly decreased the soil carbon density and moisture content in the upper $10 \mathrm{~cm}$ samples in the collapsing areas. The highest loading factors for the first principal component $(\mathrm{PC})$ extracted from the soil parameters were soil carbon and nitrogen contents, while soil moisture content and C:N ratios were the highest loading factors for the second PC. The relative abundance of Acidobacteria decreased with depth. Bacterial diversity in subsided areas was higher than that in control areas.

Conclusions: Bacterial community structure was significantly affected by $\mathrm{pH}$ and depth. The relative abundance of Gemmatimonadetes and Firmicutes were significantly correlated with the first and second PCs extracted from multiple soil parameters, suggesting these phyla could be used as indicators for the soil parameters in the thermokarst terrain.
\end{abstract}

Keywords: Permafrost degradation, Thermokarst, Relative abundance, Organic carbon, Depth, Illumina sequencing

\section{Background}

Permafrost accounts for about one quarter of land surface in the northern hemisphere. Approximately $1035 \pm 150$ Pg soil organic carbon (SOC) was stored in the upper $3 \mathrm{~m}$ soils in the circum-arctic permafrost regions [1]. The dynamics of these carbon pools can greatly change greenhouse gas concentration in the air. Permafrost degradation can result in greenhouse gas emissions and further potentially create a positive feedback to climate warming [2]. The permafrost degradation not only

\footnotetext{
*Correspondence: wuxd@|zb.ac.cn

${ }^{1}$ Cryosphere Research Station on the Qinghai-Tibetan Plateau,

State Key Laboratory of Cryospheric Sciences, Northwest Institute

of Eco-Environment and Resource, Chinese Academy of Sciences, Lanzhou 730000, Gansu, China

Full list of author information is available at the end of the article
}

stimulates decomposition of soil organic matter (SOM) due to the increasing soil temperature [3], it also affects SOC dynamics via several mechanisms such as changes in vegetation growth, dissolved organic carbon transport, and even the landform [4]. Among these mechanisms, the landform change, i.e., thermokarst formation is one of the most recognizable ground features [5]. Thermokarst greatly changes soil physico-chemical characteristics, as well as the SOC content and biodegradability [6], and thus was considered as a major source of uncertainty in predicting permafrost carbon balance [2]. Therefore, understanding the changes soil parameters and biogeochemistry in thermokarst landforms is a critical step toward the evaluation of permafrost carbon cycle.

Soil bacteria are important drivers for almost all biogeochemical cycles including that SOM decomposition 
in soils [7]. In permafrost regions, proteobacteria are usually the dominant phyla, and bacterial communities are sensitive to many biotic and abiotic factors such as $\mathrm{pH}[8,9]$, soil moisture content [10], nutrients [11] and organic carbon content [12]. Since thermokarst changes soil moisture, temperature, $\mathrm{pH}$ [13], and decreases carbon and nitrogen stocks, as well as their chemical characteristics [14], it would be reasonable to expect that thermokarst has great impacts on bacterial community structure. Although the importance of effects of thermokarst on microbes has been raised several years ago [15], reports to the bacterial community in thermokarst terrains were mainly focused on the thermokarst ponds [16, 17]. In these aquatic ecosystems, proteobacteria were also the dominant phyla and the bacterial community was affected by factors such as $\mathrm{pH}$, dissolved oxygen, dissolved organic carbon $[16,17]$. In addition to the thermokarst ponds [18], there are several typical thermokarst modes such as thaw subsidence, permafrost collapse in the terrestrial ecosystems [18]. It has been indicated that the vertical distribution pattern of bacteria has been disturbed and showed a mixed pattern in a permafrost thaw induced subsidence area [19]. However, little is known about the bacterial communities within thermokarst terrains which usually associate with removal of surface soil layers in terrestrial ecosystems.

The Qinghai-Tibetan Plateau (QTP) is the largest highlatitude permafrost region in the world. The QTP, also called "roof of the world", affects hydrothermal circulations over Asian and even the globe. The permafrost carbon pools are important for quantifying the regional and even global carbon cycle [20-22]. In comparison with the circum-Arctic regions, permafrost on the QTP is more vulnerable to global warming due to its high temperature thermal regime [23, 24], and the thaw slump, permafrost collapse has been widely recorded on the QTP [25]. Based on the knowledge that $\mathrm{pH}, \mathrm{SOC}$, and $\mathrm{C}: \mathrm{N}$ ratios are the most important factors driving soil bacterial community [12] and they vary considerably in thermokarst landforms [26], we hypothesize that permafrost collapse has great effects on bacterial communities. Specifically, we hypothesize that (1) the relative abundances of the dominant phyla showed different patterns within the microfeatures in permafrost collapse area; (2) the changes of $\mathrm{pH}, \mathrm{SOC}$, and $\mathrm{C}: \mathrm{N}$ ratios regulated soil bacterial communities in permafrost collapse-affected area; (3) the relative abundance of specific bacterial phyla showed significant changes along with the soil parameters. Since the proteobacteria are often dominant in many soils in permafrost regions, the abundancies of specific bacterial phyla can be used as indicators for the changes in soil physico-chemical characteristics. To test these hypotheses, we collected soil samples from a permafrost collapse feature on the northern QTP $[27,28]$ to investigate the bacterial communities and also examine their relationships with soil parameters.

\section{Methods \\ Site description and soil sampling}

The study area is located in a permafrost region on the northern QTP $\left(100.913^{\circ} \mathrm{E}, 38.001^{\circ} \mathrm{N}, 3661 \mathrm{~m}\right)$. The land cover is a typical alpine wet meadow, with predominant species of Kobresia tibetica Maxim., K. pygmaea, and K. humilis. According to soil taxonomy [29], the soil type is classified as Typic Haploturbel (ABGE).

The area is experiencing an active thermokarst process and there is a thermokarst gully, with a width of about $15 \mathrm{~m}$. The thawed area expands laterally upslope along the exposed headwall, and thus it is similar with thermal erosion in permafrost regions. However, there was little water flow in this gully. According to the thermokarst modes [30], this landform was more likely retrogressive thaw slumps and thus we defined it as permafrost collapse. According to the land surface characteristics, we defined three stages of the permafrost collapse: control areas (C), collapsing areas (D), and subsided areas (S) (Fig. 1). We selected three transects at the intervals of $100 \mathrm{~m}$ for sample collection along with the gully. The active layer (surface soil layer that thaws during warm season and freezes cold season) thickness varied from 70 to $120 \mathrm{~cm}$ across the microtopography. The thaw depths (which are less than active layer thickness since the active layer is the maximum thaw depth in late September) measured using a steel probe were $110 \mathrm{~cm}$ and $50 \mathrm{~cm}$ in the control and subsided areas. In the collapsing areas, the thaw depths varied from 70 to $100 \mathrm{~cm}$ due to the uneven ground surface. Soil samples were collected at depths of $0-10,10-25,25-35$, and $35-50 \mathrm{~cm}$ at the three stages, and all these samples were taken from the active layers and were not frozen during the sample collection.

The soil samples were collected aseptically using ethanol-disinfected soil augers $(3.5 \mathrm{~cm}$ in diameter) in the August 2015. At each stage, we selected $1 \mathrm{~m} \times 1 \mathrm{~m}$ plots selected to collect the soil samples. The control areas were about $10 \mathrm{~m}$ away from the gully, and the collapsing areas were located in the edges of the gully. The subside areas were located in the middle of the subsided area (about $7 \mathrm{~m}$ away from the edge of the gully). One transect has narrow boundary area, and the collapsing edge is sharp, it was difficult to collect samples from the collapsing stage, and only samples from control and subsided areas were collected (Fig. 1). For the other two transects, we collected the soil samples for all the three stages. Since there are considerable heterogeneities in soil properties within the same plots in most soils, there is a possibility that the samples used 


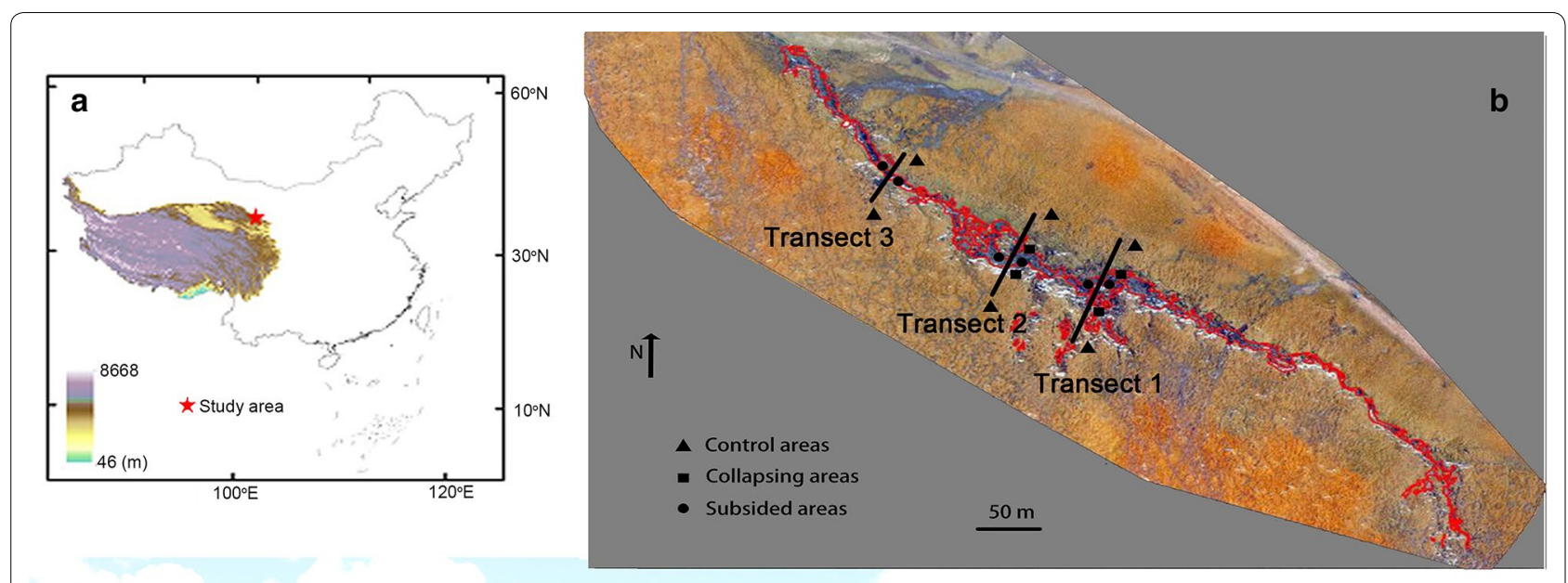

C
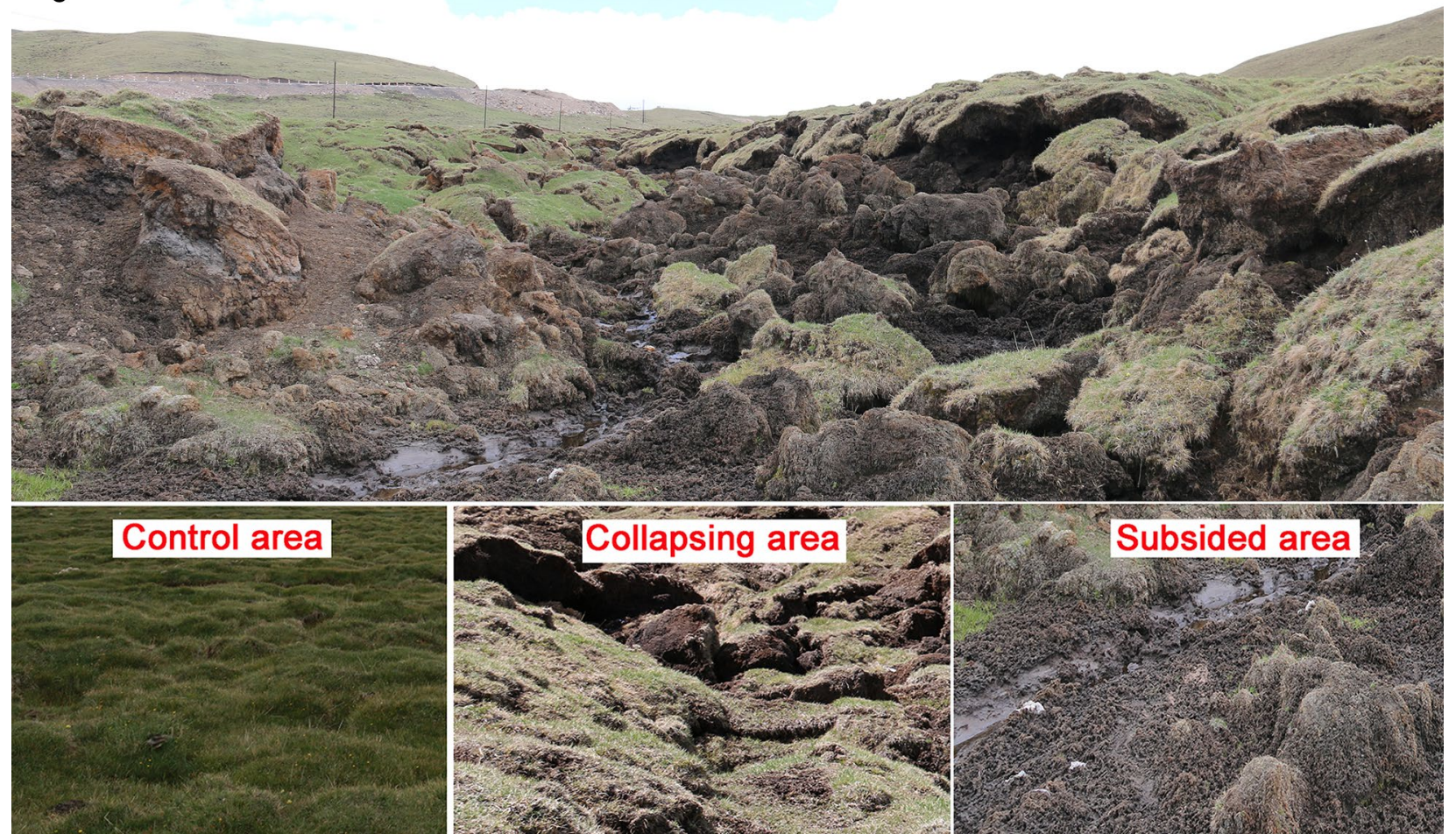

Fig. 1 Location of the study area (a) and sampling sites (b) for the three stages of permafrost collapse areas (control, collapsing, and subsided). The red line denotes the permafrost collapse-affected area. The bottom image shows (c) the three different micro-topographies

for DNA extraction were not exactly same as the samples for physico-chemical properties measurement. Therefore, we mixed five soil cores in a sterile bag to produce a sample, then we divided this mixed sample into three subsamples. This method ensured that the soil parameters and sequencing data were from same samples, although standard errors in the soil samples were measurement errors. The samples were placed in clean, sealable plastic bags, transported immediately to the laboratory in a cooler with ice packs, and stored at $-80^{\circ} \mathrm{C}$ until genomic DNA extraction was carried out.

\section{Soil parameters measurement and soil DNA extraction}

Soil moisture content was determined by drying the soil at $105{ }^{\circ} \mathrm{C}$ for $8 \mathrm{~h}$. The $\mathrm{pH}$ and conductivity of a soil suspension (1:5 soil:water ratio) were measured with an acidity meter (PHS-3C, Shanghai, China) a conductivity meter (DDS-307A, Shanghai, China). The ORP is an important driver of microbial community [31], and thus we measured the ORP in laboratory using an ORP electrode (LeiCi 501, Leici Co., Ltd., Shanghai, China), although this measurement probably could not represent the natural soil ORP values since ORP changed 
rapidly due to oxidation. Soil organic carbon (SOC), total carbon (TC) and soil inorganic carbon (SIC) of homogenized samples were quantified using dry combustion in a TOC analyzer (Vario TOC cube, Elementra, Hanau, Germany), and SOC was determined after carbonate removal [20]. Total nitrogen (TN) was measured using the micro-Kjeldhal procedure with a Foss 8400 Kjeltec analyzer (Foss Analytical Co., Ltd., Höganäs, Sweden). The C:N ratios were calculated from the mass ratio between SOC and TN. Since the samples had different bulk densities, we compared the SOC and TN densities (by multiplying contents with the dry soil bulk densities, with a unit of $\mathrm{kg} \mathrm{m}^{-3}$ ).

Total soil DNA was extracted from $0.3 \mathrm{~g}$ soil from the samples using the MoBio PowerSoil DNA Isolation kit (MoBio Laboratories, Carlsbad, CA, USA). The extracted DNA was analyzed using a QuBit DNA quantification system (Invitrogen) with QuBit high sensitivity assay reagents. All the soil DNA samples were stored frozen at $-20{ }^{\circ} \mathrm{C}$ until further analyses were performed.

\section{PCR amplification}

PCR amplification, purification, and sequencing of a region of the $16 \mathrm{~S}$ rRNA gene were performed. The V3 and $\mathrm{V} 4$ hypervariable region of the bacterial $16 \mathrm{~S}$ ribosomal RNA gene was PCR amplified $\left(94{ }^{\circ} \mathrm{C}\right.$ for $5 \mathrm{~min}$, followed by 35 cycles at $94{ }^{\circ} \mathrm{C}$ for $30 \mathrm{~s}, 54{ }^{\circ} \mathrm{C}$ for $30 \mathrm{~s}$, and $72{ }^{\circ} \mathrm{C}$ for $30 \mathrm{~s}$ and a final extension at $72{ }^{\circ} \mathrm{C}$ for $10 \mathrm{~min}$ ) with the primer set $338 \mathrm{~F}\left(5^{\prime}\right.$-ACTCCTACGGGAGGC AGCAG-3') 806R (5'-GGACTACHVGGGTWTCTAAT$3^{\prime}$ ) by thermocycler PCR system (GeneAmp 9700, ABI, USA). All PCR reactions were performed using a 50 $\mu \mathrm{L}$ reaction volume with $25 \mu \mathrm{L}$ of PCR Pre-Mixture (TaKaRa), $0.3 \mu \mathrm{M}$ of forward and reverse primers, and approximately $10 \mathrm{ng}$ of template DNA.

The PCR products and 1X loading buffer (contained SYBR green) were combined and visualized by an agarose gel electrophoresis on a $1.2 \%(\mathrm{w} / \mathrm{v})$ agarose gel under ultraviolet illumination. PCR products were purified using a QIAquick Gel Extraction Kit (Qiagen, Chatsworth, CA, USA). A single composite sample for sequencing was prepared by combining approximately equimolar amounts of PCR products from each sample. Sequencing was performed (triplicate for each sample) by Majorbio Bio-pharm Technology Co., Ltd. (Shanghai, China) using a Miseq 250.

\section{Processing of sequencing data}

Paired-end reads from the original DNA fragments were merged using FLASH when the original DNA fragments were shorter than twice the length of the reads. The sequences were processed using the QIIME software package Ver. 1.17. The singletons, reads that could not be assembled, were discarded. The chimeric sequences were identified and removed using UCHIME [32], and UPARSE (version 7.1) was used to cluster the operational taxonomic units (OTUs) with a $97 \%$ similarity cutoff. To compare of the diversity of bacterial communities in different samples, we estimated the diversity indices including the observed OTUs (which was the count of unique OTUs in the sample), Chao1, Ace, Shannon, and Simpson indices.

\section{Data analysis}

All variable measurements for each soil sample were conducted in triplicate. A one-way ANOVA with a post hoc Tukey's test was performed to compare the soil parameters and the relative abundance of bacterial phyla from the three permafrost collapse stages using R3.3.1 (http://www.rproject.org/). To test if the sequencing data could be used as indicators for the soil conditions at different stages, we extracted principal components (PCs) from the soil parameters, and then used linear regression analysis to examine the relationships between the PCs and the sequencing data. A detrended correspondence analysis (DCA) showed that the eigenvalue of the bacterial phyla was 1.4, and thus a redundancy analysis (RDA) was selected to explore the relationships between the soil parameters and bacteria phyla. The Mantel test and RDA analysis were performed using Vegan packages [33] in $\mathrm{R}$ software. The raw reads were deposited into the NCBI Sequence Read Archive (SRA) database (Accession Number: SRR5420059).

\section{Results}

\section{Bacterial diversity and community structure}

A total of 31,894 OTUs (at the $3 \%$ evolutionary distance) were identified based on 10,442 reads for each sample. The Good's coverage estimator for the OTUs ranged from 0.95 to 0.97 (Table 1), and the rarefaction curves showed that the sequences sufficiently covered the bacterial community diversity in the samples (Additional file 1: Figure S1).

The OTUs encompassed 45 phyla, 103 classes, 240 orders, 432 families and 717 genera. The bacterial community showed great variations among different samples. The most predominant phyla were Proteobacteria (42.1\%), Acidobacteria (26.6\%), Bacteroidetes (7.9\%), and Chloroflexi (5.3\%). Nitrospirae and Actinobacteria accounted for $5.0 \%$ and $4.0 \%$, respectively (Additional file 1: Figure S2).

There were markedly changes in the soil bacterial community among the three stages. For example, the 
Table 1 Estimated OTU richness, diversity indices and sample coverage

\begin{tabular}{|c|c|c|c|c|c|c|}
\hline & OTU & Ace & Chao & coverage & Shannon & Simpson \\
\hline CO_10 & 975 & 1904 & 1533 & 0.96 & 5.04 & 0.02 \\
\hline C10_25 & 913 & 1907 & 1490 & 0.96 & 4.76 & 0.04 \\
\hline C25_35 & 937 & 1922 & 1509 & 0.96 & 5.20 & 0.01 \\
\hline C35_50 & 690 & 1350 & 1095 & 0.97 & 4.62 & 0.03 \\
\hline D0_10 & 1081 & 2166 & 1735 & 0.95 & 5.33 & 0.02 \\
\hline D10_25 & 891 & 1688 & 1388 & 0.96 & 4.55 & 0.10 \\
\hline D25_35 & 910 & 1574 & 1341 & 0.97 & 5.19 & 0.02 \\
\hline D35_50 & 731 & 1238 & 1112 & 0.97 & 4.89 & 0.02 \\
\hline S0_10 & 1136 & 2051 & 1778 & 0.95 & 5.50 & 0.01 \\
\hline S10_25 & 1075 & 2080 & 1684 & 0.96 & 5.45 & 0.01 \\
\hline S25_35 & 1250 & 2290 & 1952 & 0.95 & 5.79 & 0.01 \\
\hline S35_50 & 742 & 1492 & 1206 & 0.97 & 4.40 & 0.07 \\
\hline
\end{tabular}

C, D, S means the control, collapsing, and subsided areas. 0-10, 10-20, 25-35, and 35-50 means the soil layers of 0-10 cm, $10-25 \mathrm{~cm}, 25-35 \mathrm{~cm}$, and $35-50 \mathrm{~cm}$

Proteobacteria (Fig. 2a) and Bacteroidetes (Fig. 2c) had the lowest relative abundance in the upper $10 \mathrm{~cm}$ of the samples in the collapsing areas, while the abundances of Acidobacteria (Fig. 2b) and Chloroflexi (Fig. 2d) were than those in the control and subsided areas.
At the class level, the predominant classes were Acidobacteria (15.2\%), Actinobacteria (8.4\%), Alphaproteobacteria (10.0\%), Betaproteobacteria (8.8\%), Deltaproteobacteria (7.7\%), and Gammaproteobacteria (4.9\%). The latter four classes were recorded in all the

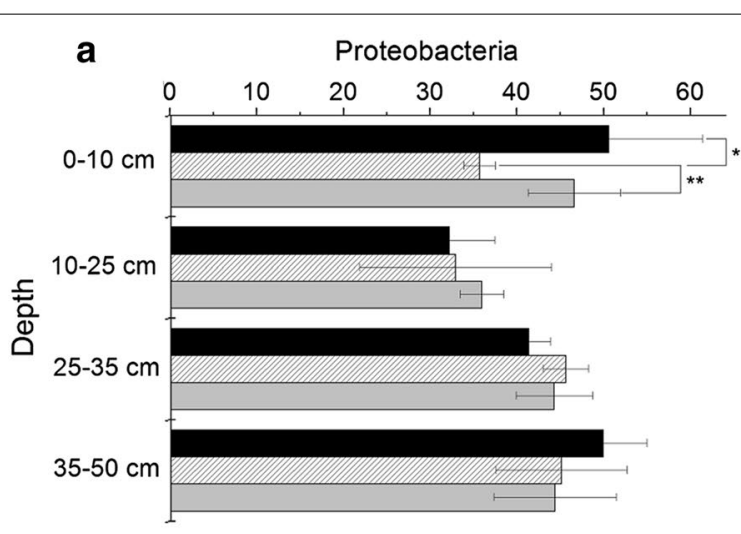

b

$\begin{array}{lllllll}0 & 10 & 20 & 30 & 40 & 50 & 60\end{array}$

C
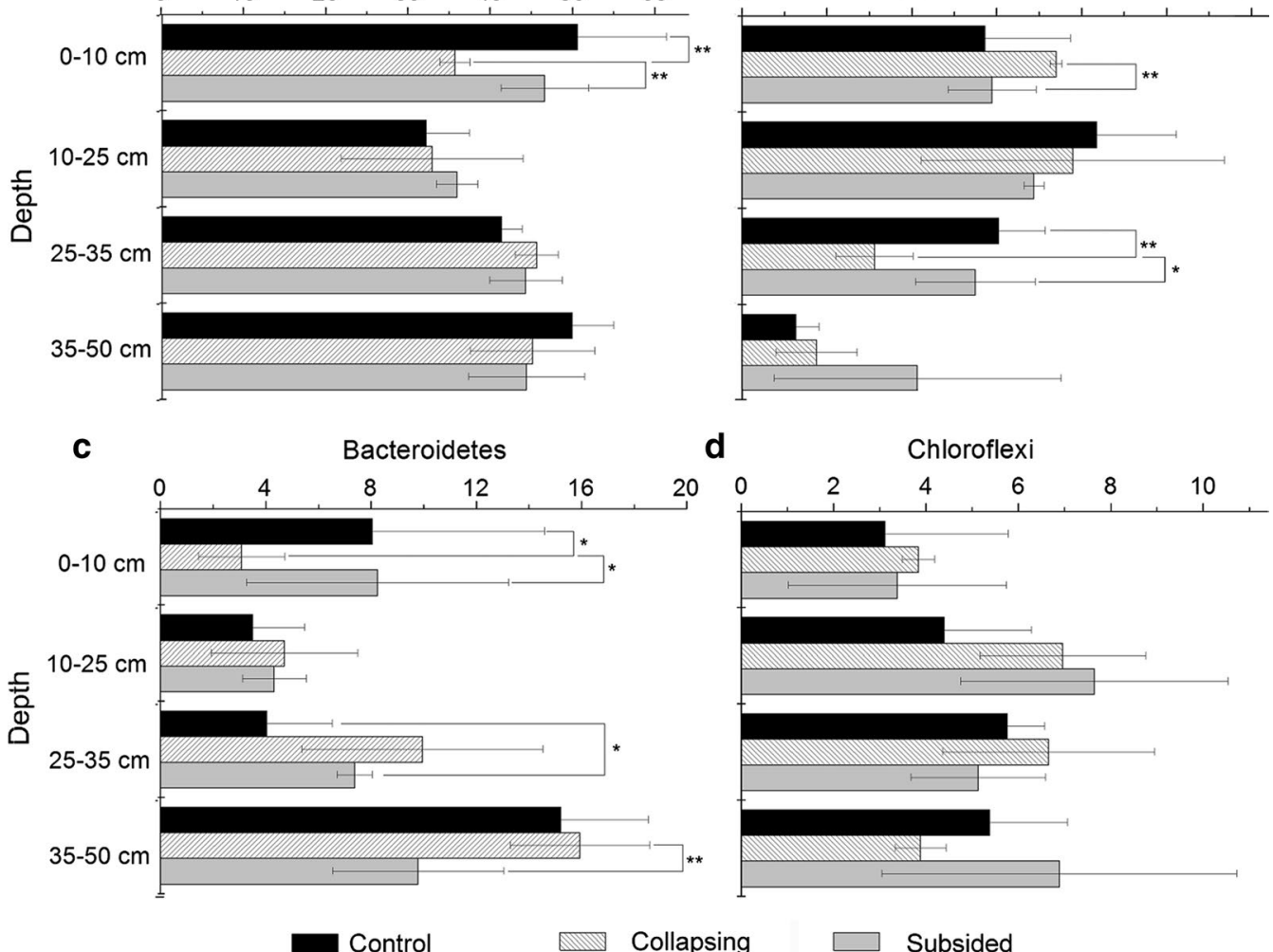

d Chloroflexi

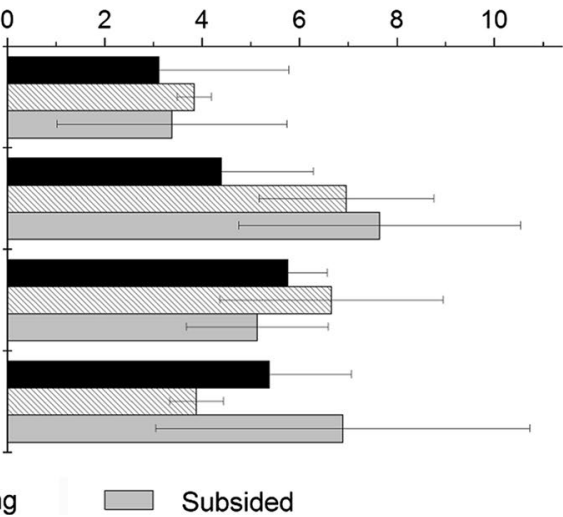

Fig. 2 Relative abundance of proteobacteria (a), acidobacteria (b), bacteroidetes (c), and chloroflexi (d) for the three stages of permafrost collapse The significant differences among the three samples were indicated $\left({ }^{*} p<0.05,{ }^{* *} p<0.01\right)$ 
samples for the Proteobacteria, but no Epsilonproteobacteria were recorded.

The OTU richness, Ace, Chao and Shannon indices were positively correlated with each other, but negatively correlated with the Simpson index (Table 1). For the mean values of the OTU richness and diversity indices at the four depths, the highest values of OTU Ace, and Chao index were all appeared in the subsided areas (Additional file 1: Table S1).

\section{Relationships among soil parameters and bacterial phyla}

Permafrost collapse obviously changed the soil physiochemical parameters (Fig. 3). For the upper $10 \mathrm{~cm}$ soil samples, TC densities in the collapsing areas were significantly lower than those of control and subsided areas, which probably due to the excessively well-drain condition and severe erosion class. The lowest soil moisture contents were recorded in collapsing soil samples. Soil $\mathrm{pH}$ values were generally lower than 7 (Fig. 3).

A Mantel test showed that the bacterial community structure was correlated with $\mathrm{pH}(\mathrm{r}=0.22, \mathrm{p}=0.007)$ and depth $(\mathrm{r}=0.306, \mathrm{p}<0.001)$, while other factors, including TC, SOC, SIC, SOC, TN, and C:N ratios, had no significant relationship with the bacterial community structure.

Depth, $\mathrm{pH}$, and ORP was significantly correlated with the relative abundance of specific phyla. TN, TC, and SIC were closely associated with the relative abundance of Nitrospirae. SOC was positively correlated with the occurrence of Bacteroidetes but negatively correlated with the relative abundance of Acidobacteria (Table 2). The most predominant phyla were Proteobacteria, and the relative abundance of Alphaproteobacteria was positively correlated with $\mathrm{pH}$ (Pearson's $\mathrm{r}=0.40, \mathrm{p}<0.05$ ) but negatively correlated with the ORP (Pearson's $r=-0.39$, $\mathrm{p}<0.05)$. There was a negative relationship between the relative abundance of Gammaproteobacteria and SOC (Pearson's $\mathrm{r}=-0.35, \mathrm{p}<0.05)$.

\section{Bacterial phyla as indicators for soil parameters}

For all the samples, there were significant relationships between SOC and TN, ORP and pH (Table 3). Five PCs were extracted from the soil parameters. The first and

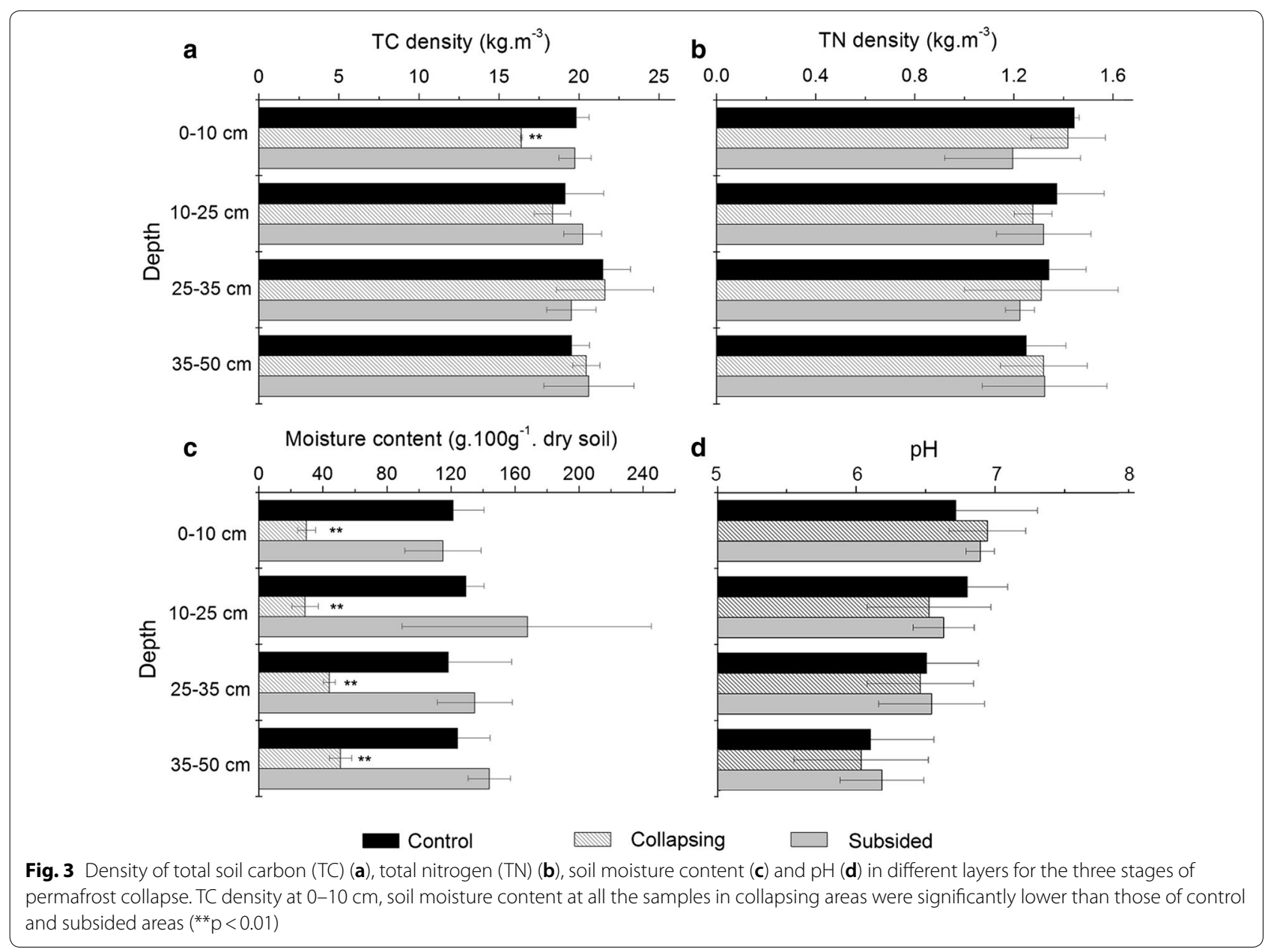


Table 2 Relationships among the soil parameters

\begin{tabular}{|c|c|c|c|c|c|c|c|c|c|c|}
\hline & Depth & Moisture & Conductivity & ORP & $\mathrm{pH}$ & TN & TC & SOC & SIC & $\mathrm{C}: \mathrm{N}$ \\
\hline Depth & 1 & & & & & & & & & \\
\hline Moisture & 0.061 & 1 & & & & & & & & \\
\hline Conductivity & -0.068 & -0.226 & 1 & & & & & & & \\
\hline ORP & $0.466^{* *}$ & 0.153 & $-0.413^{*}$ & 1 & & & & & & \\
\hline $\mathrm{pH}$ & $-0.552^{* *}$ & -0.064 & -0.060 & $-0.533^{* *}$ & 1 & & & & & \\
\hline $\mathrm{TN}$ & -0.105 & 0.099 & 0.259 & $-0.402^{*}$ & 0.300 & 1 & & & & \\
\hline $\mathrm{TC}$ & 0.281 & 0.229 & 0.220 & -0.147 & 0.011 & $0.602^{* *}$ & 1 & & & \\
\hline SOC & 0.209 & 0.331 & 0.203 & -0.128 & 0.032 & $0.573^{* *}$ & $0.896^{* *}$ & 1 & & \\
\hline $\mathrm{SIC}$ & 0.294 & 0.076 & 0.190 & -0.135 & -0.013 & $0.503^{* *}$ & $0.893^{* *}$ & $0.601^{* *}$ & 1 & \\
\hline C:N & 0.233 & 0.127 & -0.129 & 0.279 & -0.253 & $-0.711^{* *}$ & 0.047 & 0.138 & -0.055 & 1 \\
\hline
\end{tabular}

ORP, oxidation reduction potential (mv); TN, total nitrogen; TC, total carbon content; SOC, soil organic carbon content; SIC, soil inorganic carbon. Pearson's coefficient, ${ }^{*} p<0.05,{ }^{* *} p<0.01$

second PCs accounted for $59.97 \%$ of the total variances (Additional file 1: Table S2). The first PC (PC1) had highest positive loading coefficients with $\mathrm{TC}, \mathrm{SOC}$, and $\mathrm{TN}$, suggesting the organic matter contents were the most important contributing factors for this PC. The most important contributing factors for the second $\mathrm{PC}$ (PC2) were moisture content and $\mathrm{C}: \mathrm{N}$ ratios (Additional file 1: Table S3).

Linear regressions showed that the PC1 was significantly negatively correlated with the relative abundance of Gemmatimonadetes (Adjusted $\mathrm{R}^{2}=0.14, \mathrm{p}<0.02$ ) and Bacteria_unclassified (Adjusted $\mathrm{R}^{2}=0.09, \mathrm{p}<0.05$ ). The PC2 was significantly positively correlated with the relative abundance of Firmicutes (Adjusted $R^{2}=0.12$, $\mathrm{p}<0.05)$. The RDA results showed that the first and second axes explained $53.0 \%$ and $3.0 \%$ of the total phyla variances, respectively. The samples of the deeper depths $(35-50 \mathrm{~cm})$ were generally scattered in the right part of the RDA chart. The depth and $\mathrm{pH}$ were strongly correlated with the first axis. TN content was strongly correlated with the second axis (Fig. 4).

\section{Discussion}

The six dominant phyla accounted for $90.9 \%$ of the total sequences, and the number of total phyla (45) were similar with those in the central and southern QTP $[19,34]$. The predominant phyla in the present study were similar to most soils irrespective of their climatic conditions $[9,35,36]$. The lower relative abundance of Proteobacteria (Fig. 4a) and the higher abundance of Acidobacteria (Fig. $4 \mathrm{~b}$ ) in the $0-10 \mathrm{~cm}$ soil samples in the collapsing area probably can be explained by the lowest organic carbon density at this layer. Proteobacteria tend to grow in soils with high content of labile carbon [37]. In contrast, Acidobacteria usually show higher abundance in soils that have a low-quality carbon supply [37]. Similarly, members of Bacteroidetes (Fig. 4c) are thought to be associated with the degradation of organic matter [38] and thus showed lower abundances in samples in collapsing area. The highest OTUs, Ace, and Chao indices were generally recorded in the subsided areas, which probably showed the effects of labile organic matter contents in the subsided areas. The subsided areas can receive

Table 3 Relationships between soil parameters and the relative abundance of bacterial phyla

\begin{tabular}{|c|c|c|c|c|c|c|c|c|c|c|c|}
\hline & Acidobacteria & Bacteroidetes & Nitrospirae & Chlorobi & Gemma. & Aminic. & Firmicutes & Caldiserica & Bacteria_un. & Atrib. & Cyano. \\
\hline Depth & $-0 . .60^{* *}$ & $0.50^{* *}$ & -0.10 & $0.68^{* *}$ & -0.06 & $0.60^{* *}$ & -0.13 & $0.553^{* *}$ & $0.45^{* *}$ & $0.43^{*}$ & -0.25 \\
\hline Mois. & 0.06 & -0.00 & -0.15 & 0.06 & -0.07 & -0.08 & $0.601^{* *}$ & 0.00 & -0.27 & -0.18 & 0.03 \\
\hline Cond. & $-0.36^{*}$ & $0.41^{*}$ & 0.05 & -0.01 & -0.17 & 0.25 & 0.02 & 0.06 & -0.03 & 0.33 & 0.06 \\
\hline ORP & 0.09 & -0.21 & -0.17 & 0.23 & $0.38^{*}$ & -0.01 & 0.01 & 0.14 & $0.36^{*}$ & -0.08 & $-0.37^{*}$ \\
\hline $\mathrm{pH}$ & $0.45^{*}$ & $-0.40^{*}$ & 0.22 & $-0.50^{* *}$ & -0.23 & -0.29 & 0.05 & -0.34 & -0.32 & -0.10 & 0.14 \\
\hline $\mathrm{TN}$ & -0.04 & 0.17 & $0.56^{* *}$ & 0.11 & $-0.47^{* *}$ & 0.19 & 0.12 & -0.11 & -0.24 & 0.18 & -0.06 \\
\hline $\mathrm{TC}$ & -0.34 & 0.33 & $0.36^{*}$ & 0.30 & -0.21 & 0.27 & 0.10 & 0.02 & -0.06 & 0.21 & -0.08 \\
\hline SOC & $-0.36^{*}$ & $0.39 *$ & 0.22 & 0.34 & -0.23 & 0.28 & 0.30 & 0.05 & -0.01 & 0.24 & 0.03 \\
\hline $\mathrm{SIC}$ & -0.25 & 0.20 & $0.43^{*}$ & 0.19 & -0.14 & 0.21 & -0.12 & -0.01 & -0.09 & 0.12 & -0.18 \\
\hline$C: N$ & -0.22 & 0.09 & $-0.45^{*}$ & 0.12 & $0.35^{*}$ & -0.01 & 0.12 & 0.16 & 0.26 & -0.00 & 0.07 \\
\hline
\end{tabular}

Pearson's coefficient, * $\mathrm{p}<0.05$, ** $\mathrm{p}<0.01$. Moi., Soil moisture content; Cond., Conductivity; Gemma., Gemmatimonadetes; Aminic., Aminicenantes; Bacteria_un., Bacteria_unclassified; Atrib., Atribacteria; Cyano., Cyanobacteria. The proteobacteria was not significantly correlated with these parameters and was not shown 


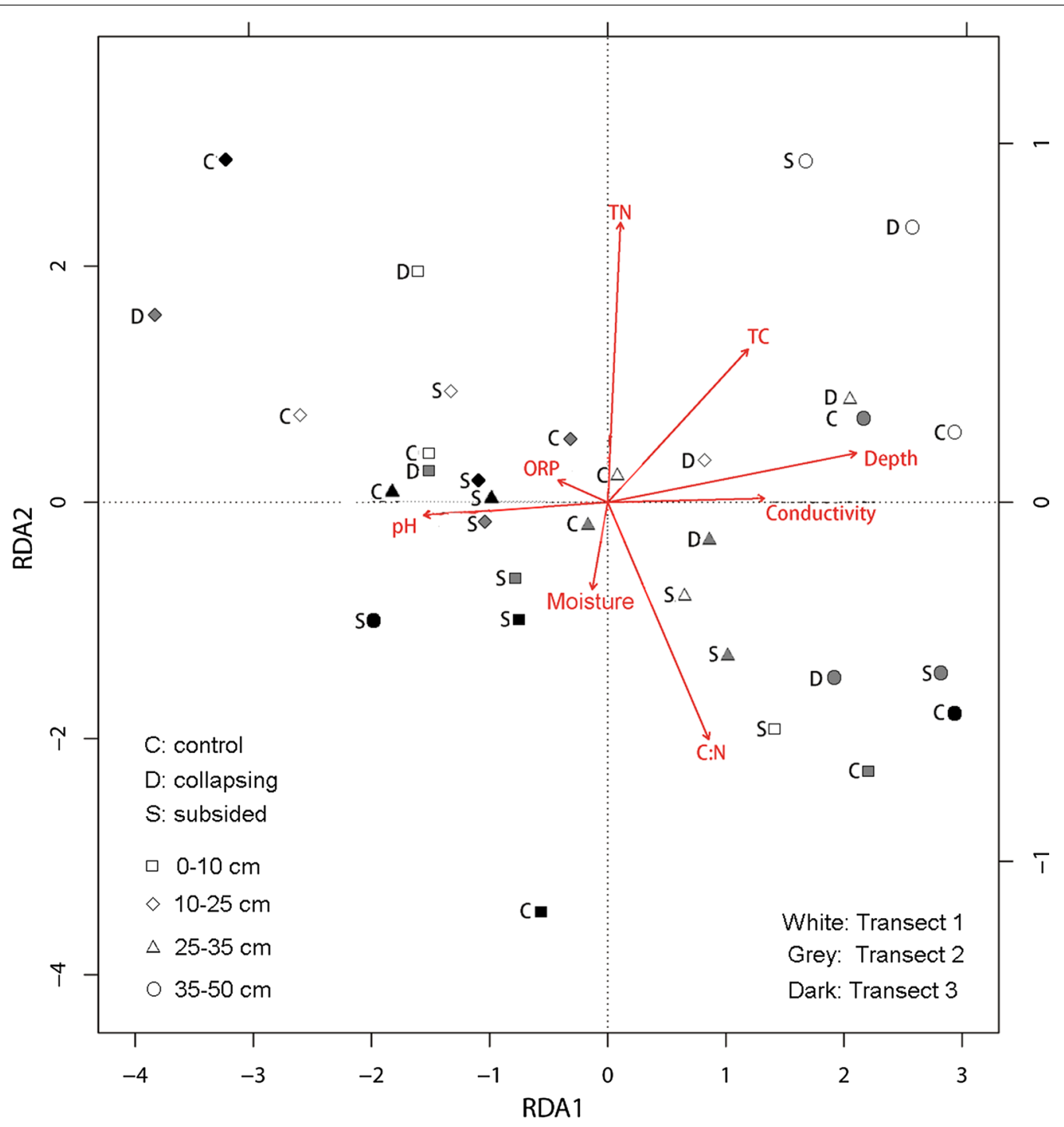

Fig. 4 A redundancy analysis (RDA) of the bacterial community structure for the samples from the three stages of permafrost collapse

dissolved organic carbon from the surrounding area [14], and the dissolved organic carbon is considered as labile substrates for microbial growth, and thus favors to the increase in soil microbial diversity [39].

The $\mathrm{pH}$ and depth were significantly correlated with bacterial community structure in this study. $\mathrm{pH}$ is the most important factor driving soil bacterial communities [40-42] since most bacterial taxa exhibit narrow growth tolerances to $\mathrm{pH}$ [36]. In subarctic areas, soil depth was one of the most important soil properties influencing bacterial community [8]. In an arid region on the western QTP, the relative abundance of Acidobacteria were higher in the near-surface layers [40]. Although the effects of depth on soil bacterial communities can be partly attributed to the $\mathrm{pH}$ because there is a significant relationship between $\mathrm{pH}$ and depth, other mechanisms are also probably responsible for the effect of depth, i.e., soil properties varied considerably at the centimeter scale in the upper soil layers $[43,44]$. In our study, the relative abundance of Acidobacteria decreased with depth, which can be explained by that most Acidobacteria favor aerobic environments and therefore decline with depth [45, 46].

The Mantel test for all the samples showed no significant relationships among soil carbon and nitrogen and bacterial community. Despite that the smaller sample size at the collapsing stage may have effects on the statistical result, this finding could be also due to the effects of thermokarst on physio-chemical parameters in these samples were uneven. For example, although the SOC 
density in the upper $10 \mathrm{~cm}$ layer in the collapsing stage was lower than that in the control and subsided areas, there were no significant differences at other depths. The non-significant relationship between SOC and bacterial community could be also explained that the SOC consists of many fractions of organic carbon, and the total SOC content was not equal to the substrate availability for bacteria [47].

The effects of ORP on bacterial communities can be partly explained by $\mathrm{pH}$ since they were significantly correlated with each other. The significant relationship between Nitrospirae and TN confirmed the fact that higher soil nutrient contents may facilitate the growth of Nitrospirae [45]. It is noteworthy that the relative abundance of Alphaproteobacteria increased along with $\mathrm{pH}$, which was consistent with the finding that this class tended to have a high relative abundance in higher $\mathrm{pH}$ conditions [48], but this finding was contrary to one study in arctic region [8]. Since such studies are scarce, future studies are required to understand the relationship between Proteobacterial classes and soil parameters.

The PC1 was significantly negatively correlated with the relative abundance of Gemmatimonadetes and Bacteria_unclassified. The Bacteria_unclassified were the sequences that could not be classified into any known group, and thus the Gemmatimonadetes could be seen as an indicator for this PC. Several studies suggested that Gemmatimonadetes be adapted to a lifestyle associated with organic matter sources that are difficult to mineralize [49]. This is a possible explanation for the fact this phylum was negatively correlated with $\mathrm{PC} 1$ in our study. The PC1 was mainly related to higher SOM contents, which usually associated with higher labile fractions [50]. The relative abundance of Firmicutes was a significant indicator for the PC2. Both laboratory experiment [51] and sequencing data from field samples [52] confirmed that this phylum as exhibiting positive response to soil moisture content.

Distribution of sampling sites on the RDA chart showed no clear pattern for the three stages of permafrost collapse, although the deepest layers $(35-50 \mathrm{~cm}$ layers) tended to appear on the right part of the chart. This result could be explained by the heterogeneity in the soil properties created by thermokarst, and no clear environmental gradient was present at the three stages. Our results showed that permafrost collapse produced a greatly heterogeneous soil environment and subsequently affected the soil bacterial community at the phyla level, and future studies are required to examine the response bacteria at genus and even family levels to environmental changes in thermokarst terrains.

\section{Conclusions}

Our study showed that the loss of organic carbon in the upper $10 \mathrm{~cm}$ samples at the collapsing area greatly decreased the relative abundance of Proteobacteria and Bacteroidetes while increased the relative abundance of Acidobacteria and Chloroflexi. The thermokarst increased the bacterial diversity in the subsided areas, a finding that may be related to the presence of higher labile fractions of organic matter. Soil parameters including depth, moisture content, ORP, soil carbon and total nitrogen content showed a significant relationship with specific phyla. The most important factors affecting bacterial communities are depth and $\mathrm{pH}$. The relative abundance of Acidobacteria decreased with depth, but no significant relationships existed between Proteobacteria and depth. Gemmatimonadetes were negatively associated with the factors which were associated with high SOM content, and Firmicutes were significantly associated with soil moisture content and $\mathrm{C}: \mathrm{N}$ ratios. These two phyla could be used as indicators for the soil parameters in the thermokarst terrain.

\section{Additional file}

Additional file 1: Table S1. The mean estimated OTU richness, diversity indices and sample coverage for the four depths. Table S2. Principle components extracted from soil variables. Table S3. Loading factors for the five principle components. Figure S1. The rarefaction curves of the samples. Figure $\mathbf{S 2}$. Relative abundance of bacterial phyla in soils from the three stages of permafrost collapse.

\section{Abbreviations}

ORP: oxidation reduction potential; QTP: Qinghai-Tibetan Plateau; SIC: soil inorganic carbon; SOM: soil organic matter; SOC: soil organic carbon; TC: total carbon; TN: total nitrogen.

\section{Authors' contributions \\ XW conceived and designed the study; HX extracted and examined the DNA samples; CM measured the physico-chemical parameters; GL prepared the data; LZ analyzed the data; All the authors wrote the paper. All authors read and approved the final manuscript.}

\section{Author details \\ ${ }^{1}$ Cryosphere Research Station on the Qinghai-Tibetan Plateau, State Key Laboratory of Cryospheric Sciences, Northwest Institute of Eco-Environment and Resource, Chinese Academy of Sciences, Lanzhou 730000, Gansu, China. ${ }^{2}$ School of Environmental and Municipal Engineering, Lanzhou Jiaotong University, Lanzhou 730070, China. ${ }^{3}$ Key Laboratory of Western China's Envi- ronmental Systems (Ministry of Education), College of Earth and Environmen- tal Sciences, Lanzhou University, Lanzhou 730000, China.}

\section{Acknowledgements}

We thank Xiaolan Zhang, Xiaoliang Ma, and Hongqin Li for their help during sample collections and laboratory analysis.

Competing interests

The authors declared that they have no competing interests. 


\section{Availability of data and materials}

Sequencing data: available on NCBI Sequence Read Archive (SRA) database (https://www.ncbi.nlm.nih.gov, Accession Number: SRR5420059).

\section{Consent for publication}

Not applicable.

\section{Ethics approval and consent to participate}

Not applicable.

\section{Funding}

This work was financially supported by the State Key Laboratory of Cryospheric Sciences (SKLCS-ZZ-2018), the National Natural Science Foundation of China (41721091, 41661013, 41871060, 41601063). This work was also supported by the Key Research Program of Frontier Sciences, CAS (Grant No. QYZDY-SSW-DQC021) and the Fundamental Research Fund for the Central Universities of China (No. Izujbky-2017-223)

\section{Publisher's Note}

Springer Nature remains neutral with regard to jurisdictional claims in published maps and institutional affiliations.

Received: 6 February 2018 Accepted: 15 August 2018

Published online: 22 August 2018

\section{References}

1. Hugelius G, Strauss J, Zubrzycki S, Harden JW, Schuur E, Ping C-L, Schirrmeister L, Grosse G, Michaelson GJ, Koven CD. Estimated stocks of circumpolar permafrost carbon with quantified uncertainty ranges and identified data gaps. Biogeosciences. 2014;11(23):6573-93.

2. Schuur E, McGuire A, Schädel C, Grosse G, Harden J, Hayes D, Hugelius G, Koven C, Kuhry P, Lawrence D. Climate change and the permafrost carbon feedback. Nature. 2015:520(7546):171-9.

3. Ping C, Jastrow J, Jorgenson M, Michaelson G, Shur Y. Permafrost soils and carbon cycling. Soil. 2015;1(1):147-71.

4. Mu CC, Abbott BW, Wu XD, Zhao Q, Wang HJ, Su H, Wang SF, Gao TG, Peng $X Q$, Zhang TJ. Thaw depth determines dissolved organic carbon concentration and biodegradability on the northern Qinghai-Tibetan Plateau. Geophys Res Lett. 2017;44(18):9389-99.

5. Jorgenson MT, Shur YL, Pullman ER. Abrupt increase in permafrost degradation in Arctic Alaska. Geophys Res Lett. 2006;33(2):L02503.

6. Abbott BW, Jones JB, Schuur EA, Chapin FS III, Bowden WB, Bret-Harte MS, Epstein HE, Flannigan MD, Harms TK, Hollingsworth TN. Biomass offsets little or none of permafrost carbon release from soils, streams, and wildfire: an expert assessment. Environ Res Lett. 2016;11(3):034014.

7. Hultman J, Waldrop MP, Mackelprang R, David MM, McFarland J, Blazewicz SJ, Harden J, Turetsky MR, McGuire AD, Shah MB, et al. Multi-omics of permafrost, active layer and thermokarst bog soil microbiomes. Nature. 2015:521(7551):208-12

8. Kim HM, Jung JY, Yergeau E, Hwang CY, Hinzman L, Nam S, Hong SG, Kim OS, Chun J, Lee YK. Bacterial community structure and soil properties of a subarctic tundra soil in Council, Alaska. FEMS Microbiolal Ecol. 2014;89(2):465-75.

9. Feng Y, Grogan P, Caporaso JG, Zhang H, Lin X, Knight R, Chu H. pH is a good predictor of the distribution of anoxygenic purple phototrophic bacteria in Arctic soils. Soil Biol Biochem. 2014;74:193-200.

10. Brockett BFT, Prescott CE, Grayston SJ. Soil moisture is the major factor influencing microbial community structure and enzyme activities across seven biogeoclimatic zones in western Canada. Soil Biol Biochem. 2012;44(1):9-20.

11. Weedon J, Kowalchuk G, Aerts R, Van Hal J, Van Logtestijn R, Taş N, Wilfred FMR, Peter MVB. Summer warming accelerates sub-arctic peatland nitrogen cycling without changing enzyme pools or microbial community structure. Glob Change Biol. 2015;18(1):138-50.

12. Zhang X, Xu S, Li C, Zhao L, Feng H, Yue G, Ren Z, Cheng G. The soil carbon/nitrogen ratio and moisture affect microbial community structures in alkaline permafrost-affected soils with different vegetation types on the Tibetan plateau. Res Microbiol. 2014;165(2):128-39.
13. Schuur EA, Vogel JG, Crummer KG, Lee H, Sickman JO, Osterkamp TE. The effect of permafrost thaw on old carbon release and net carbon exchange from tundra. Nature. 2009;459(7246):556-9.

14. Mu C, Zhang T, Zhang X, Li L, Guo H, Zhao Q, Cao L, Wu Q, Cheng G. Carbon loss and chemical changes from permafrost collapse in the northern Tibetan Plateau. J Geophys Res. 2016;121(7):1781-91.

15. Graham DE, Wallenstein MD, Vishnivetskaya TA, Waldrop MP, Phelps TJ, Pfiffner SM, Onstott TC, Whyte LG, Rivkina EM, Gilichinsky DA, et al. Microbes in thawing permafrost: the unknown variable in the climate change equation. Isme J. 2011;6:709.

16. Crevecoeur S, Vincent WF, Comte J, Lovejoy C. Bacterial community structure across environmental gradients in permafrost thaw ponds: methanotroph-rich ecosystems. Front Microbiol. 2015;6:192.

17. Negandhi K, Laurion I, Lovejoy C. Bacterial communities and greenhouse gas emissions of shallow ponds in the High Arctic. Polar Biol. 2014;37(11):1669-83.

18. Mu CC, Abbott BW, Zhao Q, Su H, Wang SF, Wu QB, Zhang TJ, Wu XD. Permafrost collapse shifts alpine tundra to a carbon source but reduces $\mathrm{N}_{2} \mathrm{O}$ and $\mathrm{CH}_{4}$ release on the northern Qinghai-Tibetan Plateau. Geophys Res Lett. 2017:44(17):8945-52.

19. Wu X, Zhao L, Liu G, Xu H, Zhang X, Ding Y. Effects of permafrost thawsubsidence on soil bacterial communities in the southern QinghaiTibetan Plateau. Appl Soil Ecol. 2018;128:81-8.

20. Mu C, Zhang T, Zhang X, Cao B, Peng X, Cao L, Su H. Pedogenesis and physicochemical parameters influencing soil carbon and nitrogen of alpine meadows in permafrost regions in the northeastern QinghaiTibetan Plateau. CATENA. 2016:141:85-91.

21. Wu X, Zhao L, Fang H, Zhao Y, Smoak JM, Pang Q, Ding Y. Environmental controls on soil organic carbon and nitrogen stocks in the high-altitude arid western Qinghai-Tibetan Plateau permafrost region. J Geophys Res. 2016:121(1):176-87.

22. Mu C, Zhang T, Wu Q, Peng X, Cao B, Zhang X, Cheng G. Organic carbon pools in permafrost regions on the Qinghai-Xizang (Tibetan) Plateau. Cryosphere. 2015;9(2):479-86.

23. Jin H, Yu Q, Wang S, Lü L. Changes in permafrost environments along the Qinghai-Tibet engineering corridor induced by anthropogenic activities and climate warming. Cold Reg Sci Technol. 2008;53(3):317-33.

24. Lin Z, Niu F, Liu H, Lu J. Disturbance-related thawing of a ditch and its influence on roadbeds on permafrost. Cold Reg Sci Technol. 2011;66(2):105-14

25. Niu F, Luo J, Lin Z, Ma W, Lu J. Development and thermal regime of a thaw slump in the Qinghai-Tibet plateau. Cold Reg Sci Technol. 2012:83:131-8.

26. Xu HY, Liu GM, Wu XD, Smoak JM, Mu CC, Ma XL, Zhang XL, Li HQ, Hu GL. Soil enzyme response to permafrost collapse in the Northern QinghaiTibetan Plateau. Ecol Ind. 2018;85:585-93.

27. Mu C, Zhang T, Cao B, Wan X, Peng X, Cheng G. Study of the organic carbon storage in the active layer of the permafrost over the Eboling Mountain in the upper reaches of the Heihe River in the Eastern Qilian Mountains. J Glaciol Geocryol. 2013;35(1):1-9.

28. Mu C, Zhang T, Wu Q, Zhang X, Cao B, Wang Q, Peng X, Cheng G. Stable carbon isotopes as indicators for permafrost carbon vulnerability in upper reach of Heihe River basin, northwestern China. Quatern Int. 2014;321:71-7.

29. Soil Survey Staff. Keys to soil taxonomy, twelfth edition: USDA-Natural resources conservation service. Washington, DC: Soil Survey Staff; 2014

30. Kokelj SV, Jorgenson MT. Advances in thermokarst research. Permafrost Periglac Process. 2013;24(2):108-19.

31. Husson O. Redox potential (Eh) and pH as drivers of soil/plant/microorganism systems: a transdisciplinary overview pointing to integrative opportunities for agronomy. Plant Soil. 2013:362(1-2):389-417.

32. Edgar RC, Haas BJ, Clemente JC, Quince C, Knight R. UCHIME improves sensitivity and speed of chimera detection. Bioinformatics. 2011;27(16):2194-200.

33. Oksanen J, Blanchet F, Kindt R, Legendre P, Minchin R, O'Hara R. Vegan: community ecology package version 2.0-10. J Stat Softw. 2013:48(9):103-32.

34. Wu XD, Xu HY, Liu GM, Ma XL, Mu CC, Zhao L. Bacterial communities in the upper soil layers in the permafrost regions on the Qinghai-Tibetan plateau. Appl Soil Ecol. 2017;120:81-8. 
35. Wallenstein MD, Mcmahon S, Schimel JP. Bacterial and fungal community structure in Arctic tundra tussock and shrub soils. FEMS Microbiol Ecol. 2007;59(2):428-35.

36. Rousk J, Baath E, Brookes PC, Lauber CL, Lozupone C, Caporaso JG, Knight $\mathrm{R}$, Fierer $\mathrm{N}$. Soil bacterial and fungal communities across a pH gradient in an arable soil. ISME J. 2010;4(10):1340-51.

37. Fierer N, Bradford MA, Jackson RB. Toward an ecological classification of soil bacteria. Ecology. 2007;88(6):1354-64.

38. Makonde HM, Mwirichia R, Osiemo Z, Boga HI, Klenk HP. 454 Pyrosequencing-based assessment of bacterial diversity and community structure in termite guts, mounds and surrounding soils. SpringerPlus. 2015:4:471.

39. Berthrong ST, Buckley DH, Drinkwater LE. Agricultural management and labile carbon additions affect soil microbial community structure and interact with carbon and nitrogen cycling. Microb Ecol. 2013;66(1):158-70.

40. Chu H, Sun H, Tripathi BM, Adams JM, Huang R, Zhang Y, Shi Y. Bacterial community dissimilarity between the surface and subsurface soils equals horizontal differences over several kilometers in the western Tibetan Plateau. Environ Microbiol. 2016;18(5):1523-33.

41. Tripathi BM, Kim M, Singh D, Leecruz L, Laihoe A, Ainuddin AN, Go R, Rahim RA, Husni MHA, Chun J. Tropical soil bacterial communities in Malaysia: pH dominates in the equatorial tropics too. Microb Ecol. 2012;64(2):474-84.

42. Fierer N, Jackson RB. The diversity and biogeography of soil bacterial communities. Proc Natl Acad Sci USA. 2006;103(3):626-31.

43. Wu X, Zhao L, Chen M, Fang H, Yue G, Chen J, Pang Q, Wang Z, Ding Y. Soil organic carbon and its relationship to vegetation communities and soil properties in permafrost areas of the Central Western Qinghai-Tibet Plateau, China. Permafrost Periglac Process. 2012;23(2):162-9.
44. Dorfer C, Kuhn P, Baumann F, He JS, Scholten T. Soil organic carbon pools and stocks in permafrost-affected soils on the Tibetan plateau. PLOS ONE. 2013;8(2):e57024

45. Li C, Yan K, Tang L, Jia Z, Li Y. Change in deep soil microbial communities due to long-term fertilization. Soil Biol Biochem. 2014;75:264-72.

46. Hamamura N, Olson SH, Ward DM, Inskeep P. W: microbial population dynamics associated with crude-oil biodegradation in diverse soils. Appl Environ Microbiol. 2006;72(9):6316.

47. Andersson S, Nilsson SI. Influence of pH and temperature on microbial activity, substrate availability of soil-solution bacteria and leaching of dissolved organic carbon in a mor humus. Soil Biol Biochem. 2001;33(9):1181-91.

48. Bartram AK, Jiang X, Lynch MDJ, Masella AP, Nicol GW, Dushoff J, Neufeld JD. Exploring links between $\mathrm{pH}$ and bacterial community composition in soils from the Craibstone Experimental Farm. FEMS Microbiol Ecol. 2014;87(2):403-15.

49. Whitman T, Pepe-Ranney C, Enders A, Koechli C, Campbell A, Buckley $\mathrm{DH}$, Lehmann J. Dynamics of microbial community composition and soil organic carbon mineralization in soil following addition of pyrogenic and fresh organic matter. Isme J. 2016;10:2918

50. Wu XD, Zhao L, Hu G, Liu GM, Li WP, Ding YJ. Permafrost and land cover as controlling factors for light fraction organic matter on the southern Qinghai-Tibetan Plateau. Sci Total Environ. 2018;613-614:1165-74.

51. Placella SA, Brodie EL, Firestone MK. Rainfall-induced carbon dioxide pulses result from sequential resuscitation of phylogenetically clustered microbial groups. Proc Natl Acad Sci USA. 2012;109(27):10931-6.

52. Mchugh TA, Koch GW, Schwartz E. Minor changes in soil bacterial and fungal community composition occur in response to monsoon precipitation in a semiarid grassland. Microb Ecol. 2014;68(2):370-8.
Ready to submit your research? Choose BMC and benefit from:

- fast, convenient online submission

- thorough peer review by experienced researchers in your field

- rapid publication on acceptance

- support for research data, including large and complex data types

- gold Open Access which fosters wider collaboration and increased citations

- maximum visibility for your research: over 100M website views per year

At BMC, research is always in progress.

Learn more biomedcentral.com/submissions 